\section{Bolivia's Emerging Cut-flower Industry: A Performance Assessment}

John J. Haydu

University of Florida, Institute of Food and Agricultural Sciences, Central Florida Research and Education Center, 2807 Binion Road, Apopka, FL 32703

\author{
Alan W. Hodges \\ University of Florida, Institute of Food and Agricultural Sciences, Food \\ and Resource Economics Department, Gainesville, FL 32611
}

\section{Diego Montenegro \\ Ronco Development Corporation, La Paz, Bolivia}

Additional index words. business analysis, labor, capital, fixed and variable costs

\begin{abstract}
Cut-flower production in Bolivia is a growing economic activity with sales increasing $>10$-fold in the past 6 years. In spite of this growth, Bolivian producers face considerable financial difficulties. Two distinct patterns emerged from this study. Small and medium growers experienced lower costs than larger producers, but the prices they received were also lower. Large operators received twice the small producer price for their flowers, but this gain was offset by the higher costs they had incurred. In the long term, neither selling too low nor operating at costs too high is a sustainable practice.
\end{abstract}

Cut-flower production, consisting primarily of roses (Rosa hybrida L.), represents a relatively new agricultural activity in Bolivia. Although some production was reported as early as 1984, the emergence of commercial operations is even more recent. For example, export sales of roses amounted to only $\$ 72,000$ in 1986 . At that time, the industry consisted of $\approx 20$ producers with a total growing area of 15 ha (Montenegro, 1989). In the past few years, small farmers, or campasinos, have emerged as another class of grower interested in cut-flower production. So far, however, they remain a minor contributor to total industry sales.

Climatic conditions appear favorable most of the year for flower production, particularly in Bolivia's Cochabamba Valley (elevation $2600 \mathrm{~m}$; mean annual precipitation $600 \mathrm{~mm}$; temperatures range from -5 to $34 \mathrm{C}$ ), but start-up costs can be considerable. Three types of initial investments are essential for year-round production. First, greenhouses must be built to protect the plants from periodic harmful weather, particularly freezing temperatures and high winds developing in the early spring. Second, an irrigation system is necessary. Third, and perhaps the most significant start-up cost, is the producer's purchase of stock plants. Imported from the United States, stock plants reportedly accounted for $48 \%$ of the initial investment of flower nurseries in 1987 (Montenegro, 1989). In total, these three costs represent

Received for publication 12 Mar. 1992. Accepted for publication 23 July 1992. Florida Agricultural Stations Journal Series no. R-02205. The cost of publishing this paper was defrayed in part by the payment of page charges. Under postal regulations, this paper therefore must be hereby marked advertisement solely to indicate this fact. an appreciable capital investment and carry with them potentially high levels of financial risk to prospective producers.

Although it is still in its early stages, there is some concern whether Bolivia's commercial flower industry can sustain itself, particularly given interest rates of $18 \%$ and the presence of low-cost, high-volume Colombian producers who currently dominate cutflower sales to the United States. The purpose of this study was to construct an economic profile of the cut-flower production industry and develop criteria to assess the current financial performance of producers. A related objective was to determine if economies of size were substantial enough to enhance industry competitiveness.

At the time this study was conducted (Sept.- Oct. 1991), 23 cut-flower producers were identified through a grower list provided by the cooperative association ASOBOFLOR. All producers were located in the Cochabamba Valley of Bolivia. Thirteen of these growers were interviewed, which represented $57 \%$ of the study population. However, since nearly all large producers were a total of $2080 \mathrm{~h} \cdot \mathrm{year}^{-1}$. interviewed, this figure likely accounted for between $80 \%$ and $90 \%$ of industry supply in 1990 (E. Ponce, personal communication). Respondents from this population were selected randomly, but with a desired target of four respondents for each size category. Given the relatively small number of producers, the objective was to develop a representative portrait of firms within three separate size categories: 1) small, <3000 m²; 2) medium, 3000 to $6000 \mathrm{~m}^{2}$; and 3) large, $>6000 \mathrm{~m}^{2}$. The sampling distribution constituted a breakdown of five small, three medium, and five large firms interviewed.

The survey instrument used for the study was adapted from the Institute of Food and Agricultural Science's Business Analysis Program ( Univ. of Florida, 1992). This program was started in 1967 for Florida's ornamental horticulture industry and has been used since then to evaluate the financial performance of nurseries and greenhouses. The survey instrument was tested by us and revised three times to accurately represent local nursery conditions. Growers used in the testing procedure were not part of the sample population. The questionnaire was also translated into Spanish to facilitate interviews. Because detailed financial data were crucial to the study, personal interviews were conducted. Most interviews were $\approx 3 \mathrm{~h}$ long; however, some of the larger growers required additional time. Finally, to accurately assess production costs and the firm's financial performance, it was necessary that the study period cover a full 12 months. As a result, 1990 became the most recently available period to collect this information. Most of the information was collected from grower records and the financial statements of the cooperative. The cooperative not only provided input supplies to the grower, it also assembled, packaged, distributed, and sold the flowers in local or international markets. In the case of a few small growers who had incomplete expenditure records, estimates were constructed from remaining inventories and the growers' recollection of expenditures.

To provide a more consistent basis for inter-firm comparisons, a systematic approach to examining certain variables was employed. An illustration of this process concerns operator salaries. Although most owners were paid a salary directly from business earnings, some were paid indirectly through

Table 1. Differences in business size for cut flowers according to sales, production area, number blooms produced, labor use, and total managed capital, Bolivia, 1990.

\begin{tabular}{|c|c|c|c|c|c|}
\hline $\begin{array}{l}\text { Firm } \\
\text { size }^{y}\end{array}$ & $\begin{array}{c}\text { Rose } \\
\text { sales } \\
(\$)\end{array}$ & $\begin{array}{c}\text { Production } \\
\text { area } \\
\left(\mathrm{m}^{2}\right)\end{array}$ & $\begin{array}{c}\text { Blooms } \\
\text { produced } \\
\text { (no.) }\end{array}$ & $\begin{array}{l}\text { Labor } \\
\text { use } \\
\text { (FTEx) }\end{array}$ & $\begin{array}{l}\text { Managed } \\
\text { capital }^{\mathbf{z}} \\
(\$)\end{array}$ \\
\hline Small & 5,000 & 1,390 & 86,000 & 3.3 & 151,000 \\
\hline Medium & 30,000 & 4,500 & 343,000 & 8.6 & 756,000 \\
\hline Large & 128,000 & 10,100 & 869,000 & 10.3 & $2,046,000$ \\
\hline Avg & $58,000^{w}$ & 5,460 & 395,000 & 7.2 & $1,019,000$ \\
\hline
\end{tabular}

${ }^{2}$ Managed capital is the value of capital owned plus the value of capital leased.

${ }^{y}$ Small $\left(<3000 \mathrm{~m}^{2}\right)$; medium $\left(3000-6000 \mathrm{~m}^{2}\right)$; Large $\left(>6000 \mathrm{~m}^{2}\right)$.

Full-time equivalent (FTE) is defined as a person working $8 \mathrm{~h} \cdot$ day $^{-1}, 40 \mathrm{~h} \cdot$ week $^{-1}$ for 52 weeks, for

wotal value of sales of the sample of 13 firms was $\$ 749,554$ in 1990 . 
Table 2. Distribution of managed capital in dollars and as a percentage of total (in parentheses) for the study" sample of firms, Bolivia, 1990.

\begin{tabular}{lcccc} 
& \multicolumn{4}{c}{ Firm size } \\
\cline { 2 - 5 } Capital & Small & Medium & Large & Avg \\
\hline \multirow{5}{c}{ Dollars } \\
Plants & 31,100 & 175,900 & 234,800 & 142,800 \\
& $(33)$ & $(44)$ & $(46)$ & $(45)$ \\
Land & 51,300 & 129,300 & 100,900 & 88,400 \\
& $(55)$ & $(32)$ & $(20)$ & $(27)$ \\
Buildings & 7,900 & 73,100 & 120,900 & 66,400 \\
& $(10)$ & $(18)$ & $(24)$ & $(21)$ \\
Machinery/ & \multicolumn{4}{c}{} \\
equipment & 1,000 & 14,400 & 18,500 & 10,800 \\
& $(1)$ & $(4)$ & $(5)$ & $(3)$ \\
Cash on hand & 900 & 2,800 & 16,300 & 7,300 \\
& $(1)$ & $(1)$ & $(3)$ & $(2)$ \\
Other ${ }^{\mathbf{y}}$ & 300 & 2,300 & 14.5 & 6,200 \\
& $(--)$ & $(1)$ & $(2)$ & $(2)$ \\
Total & 92,600 & 398,000 & 506,200 & 322,200 \\
& $(100)$ & $(100)$ & $(100)$ & $(100)$ \\
\hline
\end{tabular}

${ }^{2}$ Figures represent a weighted average of firms within each cell. Total column is weighted average for all procedures.

'Figures in parentheses represent the cell's percentage of column total.

${ }^{x}$ Supplies and accounts receivable.

"outside" sources of income. In these cases, an estimate of the value of the operator's time was collected in lieu of actual payments.

A second illustration of this approach dealt with the method of handling capital. All capital investments, consisting primarily of buildings, machinery, and equipment, were depreciated to reflect their book value. Stock plants also were included as part of the capital investment. However, since the primary cut flower in this study was a rose (a perennial plant), its product (the rose bloom) represented a flow of income over time. Since the intent of the study was to establish the grower's current financial position and not the business's ability to generate income, only those costs that were invested in the plant from the time it was purchased up until the interview date were considered. This value included the plant's original cost and all the direct costs associated with its production and maintenance, including pesticides, fertilizers, fuel, electricity, and labor. The purpose of this approach was to establish a firm's value via cost (as opposed to sales), and to include only those expenses that could be attributed directly to the plant's production and care.

Size of business. The sale of roses averaged $\$ 5000$ for small producers, nearly $\$ 30,000$ for medium-sized producers, and $\$ 128,000$ for the growers in the largest category (Table 1). The value of roses sold was 26 times greater for a typical large producer than it was for an average small one. For the study sample, total value of sales amounted to $\$ 749,500$. Among the firms examined, most were relatively small, with only one grower having a production area $>1$ ha. A firm-size comparison reveals that greenhouses averaged $1390 \mathrm{~m}^{2}$ for small producers, $4500 \mathrm{~m}^{2}$ for medium-sized firms, and $10,105 \mathrm{~m}^{2}$ for the largest producers, compared with the mean growing area for U.S. producers in 1988, which was $9676 \mathrm{~m}^{2}$, or about twice the size of a typical Bolivian producer (U.S. Dept. of Agriculture, 1988). Although cut-flower operations in both countries are small relative to other comparably aligned industries, such as Florida's foliage nurseries, which have production areas nearly 10 times larger than these estimates (Strain and Hodges, 1989a), even these sizes imply a considerable investment in production and management resources. For example, using an industry average of eight plants per square meter, a medium-sized grower would have 36,000 rosebushes to care for, manage, harvest, process, and sell. Labor use patterns reflect the intensive nature of cut-flower production. By taking the growing area from the average firm $\left(5480 \mathrm{~m}^{2}\right)$ and dividing it by the average full-time equivalent hours (FTE; 7.2), we find that an average full-time person is responsible for 750 $\mathrm{m}^{2}$ of greenhouse area, or 13.33 FTE/ha. This figure is consistent with labor use patterns for flowering plant nurseries in Florida (1 FTE per $864 \mathrm{~m}^{2}$ ), an industry requiring similar production management activities (Strain and Hodges, 1989b).

Labor-use patterns varied considerably across size of operations (Table 1). Labor use differed markedly between producers in the small and medium groups (from 3.3 to 8.6 FTE) but only marginally between producers in the medium and large groups $(8.6$ to 10.3 FTE). This relationship suggests that small producers may have avoided certain

Table 3. Variable, fixed, and total cost of production of roses, in percentage of total costs and dollars per square meter, by size of operation, Bolivia, 1990.

\begin{tabular}{|c|c|c|c|c|}
\hline \multirow[b]{2}{*}{ Type of cost } & \multicolumn{4}{|c|}{ Firm size } \\
\hline & Small & Medium & Large & Avg \\
\hline $\begin{array}{l}\text { Variable (\$) } \\
\%^{y} \\
\$ / m^{2}\end{array}$ & $\begin{array}{l}3,400 \\
76 \\
2.48\end{array}$ & $\begin{array}{r}26,900 \\
37 \\
5.99\end{array}$ & $\begin{array}{r}88,300 \\
54 \\
8.74\end{array}$ & $\begin{array}{r}1,400 \\
51 \\
7.60\end{array}$ \\
\hline $\begin{array}{c}\text { Fixed }(\$) \\
\% \%^{y} \\
\$ / m^{2} \\
\text { Total }(\$) \\
\%^{y} \\
\$ / m^{2} \\
\end{array}$ & $\begin{array}{c}1,100 \\
24 \\
0.82 \\
4,600 \\
100 \\
3.30\end{array}$ & $\begin{array}{c}45,400 \\
63 \\
10.10 \\
72,400 \\
100 \\
16.09\end{array}$ & $\begin{array}{c}74,000 \\
46 \\
7.33 \\
162,300 \\
100 \\
16.06\end{array}$ & $\begin{array}{c}39,400 \\
49 \\
7.21 \\
80,900 \\
100 \\
14.81\end{array}$ \\
\hline
\end{tabular}

${ }^{\text {zFigures represent a weighted average of firms within each cell. Total column is weighted average for }}$ all producers.

${ }^{y}$ Figures represent the cell's percentage of column total.

cultural practices adopted by larger nurseries or managed their crops either less intensively or more efficiently.

Capital managed is the value of the capital owned plus the value of capital used, such as leased property. Leased capital, however, did not exist among those interviewed. Capital owned is the value of capital assets in the nursery operation, including the stock plants, equipment, buildings, land, accounts receivable, and cash on hand. For the nurseries interviewed, the average value of capital managed corresponded closely with nursery size (Table 1).

Distribution of managed capital. At $\$ 322,000$, capital expenditures constituted a major investment for the average flower producer (Table 2). Of the six capital resource categories, stock plants represented the single largest investment, with $45 \%$ of the total. This figure is consistent with those of Montenegro (1989). Given its obvious impact on start-up costs and short-term profitability, less expensive alternatives for starter plants would be desirable but may not be horticulturally feasible. Carried further, depending on the resources available to producers, current investment levels may behave as twin barriers to this industry-first, as a deterrent to new firms seeking to establish themselves, and second, by constraining or altogether stopping existing firms from expanding their operations further,

Land was the second most important factor of production, accounting for an average $27 \%$ of the value of capital resources. However, because most respondents had ownership before starting the nursery, land did not constitute an initial investment. In this sense, land had a positive effect on the firm's balance sheet since it represented a portion of the owner's equity. One important element of equity is that it contributes to the firm's ability to meet all debt when assets are sold (van Blokland, 1987). Greater solvency is beneficial during protracted economic slumps or when firms are experiencing cash-flow difficulties.

Buildings, which include greenhouses, packing rooms, and cold-storage units, were the third most important resource, representing $21 \%$ of total capital. Only a few growers had packing and cold-storage units, however. Most producers relied on the local cooperative association, ASOBOFLOR, and its marketing unit, SERVIFLOR, to assemble and process their roses for sale. Members were charged a flat rate of $20 \%$ of gross sales for this service. Finally, machinery and equipment were the fourth-ranked category but, at only $3 \%$ of the total, were of minor significance as a capital expenditure. Within this category, the most important cost was for irrigation equipment, such as electric pumps, water lines, and sprinkler heads.

Small growers were capitalized relatively less than larger growers (Table 2). This finding was also evident during the interviews and on-site visits. On the whole, small producers had invested as little as possible. Structures were made simply, and costly equipment was avoided. What these differ- 
Table 4. Break even analysis using variable, fixed, and total cost of production for cut-flower producers, Bolivia, 1990.

\begin{tabular}{lcccc}
\hline \multirow{2}{*}{$\begin{array}{l}\text { Cost/price } \\
\text { category }\end{array}$} & \multicolumn{4}{c}{ Firm size } \\
\cline { 2 - 5 } & Small & Medium & Large & Avg \\
\hline Price received & \multicolumn{5}{c}{$\$ /$ Bloom } \\
Cost incurred & 0.05 & 0.06 & 0.20 & 0.11 \\
$\quad$ Variable & 0.08 & 0.05 & 0.08 & 0.10 \\
Fixed & 0.03 & 0.05 & 0.09 & 0.09 \\
$\quad$ Total & 0.11 & 0.10 & 0.17 & 0.19 \\
Profit/(loss) & $(6)$ & $(4)$ & 3 & $(8)$ \\
\hline
\end{tabular}

2Prices were calculated from sales and production information for each grower, acquired through the marketing cooperative ASOBOFLOR.

ences may signify in the long term is unclear. For instance, there could be a correlation between the quality of the production environment and the quality of the cut flower. Growers who chose more expensive, stateof-the-art facilities should be better equipped to control harmful diseases and pests; they should also have greater control over postharvest conditions. Once flowers are cut, proper handling and storage are crucial factors affecting quality. Roses can be stored for extended periods under proper conditions and can be expected to have the same life and quality as fresh-cut flowers (Mastalerz, 1969). Cold-storage capability has important marketing implications as well. In Poland, for example, producers are addressing unequal demand and frequent disturbances on the flower market through prolonged cold storage (Lakaszewska and Jablonska, 1991).

Fixed and variable costs of production. Typical fixed costs are depreciation, taxes, interest, and some types of repairs. Conversely, expenditures on inputs such as fertilizer, pesticides, soil amendments, and potting containers are directly related to the volume of output; i.e., they are variable costs. For the average producer in this study, fixed and variable costs were nearly identical (Table 3). However, differences across firm size were evident. Campasinos invested little in buildings, machinery, and equipment, and their fixed costs reflected this practice (about one-fourth of total cost). However, fixed costs for medium-sized producers accounted for nearly two-thirds of total costs. In percentage terms, fixed and variable costs incurred by the largest producers fell about halfway between these two values. Finally, total costs varied considerably by firm size: $\$ 4500$ for the average small producer; 16 times more for a producer in the middle category; and 36 times more for the average large producer, although other factors of production differed considerably less. For instance, production area for medium and large growers exceeded that of small growers by factors of only 3 and 7 , respectively (Table 1 ). Similarly, in contrast to the small producer group, labor use was only three times greater for the two larger size categories.

A second useful way to examine production costs is per square meter of greenhouse space. This type of analysis is useful for comparing costs across producer groups or for uncovering differences in production or cultural practices (e.g., low variable costs might indicate less intensive production and management practices). The average producer in this study had $\$ 7.60 / \mathrm{m}^{2}$ in variable costs and $\$ 7.21 / \mathrm{m}^{2}$ in fixed costs. Again, a farm-size comparison revealed that smaller growers had substantially lower costs on a production-unit basis. For example, their total costs were about one-third those for the medium and large producers.

Lower costs by themselves, however, do not necessarily indicate efficiency. Rather, costs of production must be related to some measure of output. One indicator of efficiency is the number of salable blooms per square meter of growing area (production efficiency). From Table 1, the production efficiency is derived by dividing production area (second column) with the number of roses produced (third column). Thus, small producers averaged 62 , medium growers 76 , and the largest producers 86 blooms $/ \mathrm{m}^{2}$, indicating a direct relationship between production efficiency and the size of a grower's operation.

A second efficiency measure examines dollars of inputs used (total cost) to produce a unit of output, such as a bundle of 2.5 roses or a single rose bloom (cost efficiency). Results of cost efficiency, also called "break even" analysis (Table 4), suggest that producers in general were not operating profitably. The average grower did not receive an adequate price to cover the total cost of production. Growers were just able to cover direct operating expenses (variable costs of $\$ 0.10$ per bloom) but were unable to meet their additional overhead expenses (fixed cost of $\$ 0.09$ per bloom). Using a firm-size comparison, a nearly direct cost-price relationship was found among the sample of growers. Small and medium producers experienced lower costs than larger producers, but the prices they received were also lower. In the end, lower costs that should have given small growers an economic edge were undermined by the growers' inability to capture a better price. Large producers, on the other hand, incurred substantially higher costs but at the same time received higher prices for their roses, in fact, more than enough to offset any cost disadvantage. However, when viewed strictly from a cost-efficiency standpoint, results do not support the notion that large growers benefited from their larger-scale operations.

Despite barriers to entry into Bolivia's cutflower industry, there are indications of impressive growth. The sale of roses grew from $\$ 72,000$ for the industry as a whole in 1984 to nearly $\$ 750,000$ for the 13 firms studied in 1990, a IO-fold increase. More than $80 \%$ of those sales came from the three largest firms. A few firms in the sample were recent entrants who had constructed greenhouse facilities but had not yet begun selling their product. Other existing firms were expanding their operations. The combination of these two factors suggests that the industry will continue to grow, at least for the next few years, but several observations are notewor- thy within the context of this statement.

First, industry growth should not be confused with economic viability or sustainability over time. Results of this study found that most respondents were not operating profitably. Poor financial performance may partly be explained by the fact that some firms were new and production was limited to start-up levels. Yet even granting this concession, most producers were selling their product well below cost. Two distinct patterns emerged: 1) Although small- and medium-sized 'growers were the lowest-cost producers, they were unable to extract an adequate price to cover those costs. And although large producers received substantially higher prices for their roses, much of this gain was offset by the higher costs they incurred. Even so, only this group of producers was operating profitably. 2) From the product and cost-efficiency indicators examined, benefits that can be attributed directly to an increase in firm-size are inconclusive. Although there was a relationship between a producer's size and production efficiency (i.e., growers in the largest category produced $27 \%$ more blooms per square meter than did small operators), when relating size to costs of production, the issue becomes clouded. To support the presence of size economies with respect to costs, total expenditures on a unit-area basis should decline. In fact, the relationship was opposite: costs actually rose with a corresponding increase in size. Consequently, even though larger producers were able to benefit from certain efficiencies in production, they were unable to capture similar gains on the financial end of their business.

Further investigation into cost and price differentials across size categories should be undertaken. What, for instance, is the relationship between the type and cost of a grower's production facility and the quality of final product? We found that small producers' costs were lower primarily because they invested less in their capital and equipment. Although variable costs were similar, fixed costs per bloom were three times higher for large firms than they were for small ones. But in the longer term, these apparent advantages for small producers were less certain. Why, for instance, did small- and medium-sized growers receive only one-third the price of large producers, and how much of this price difference can be attributed to quality?

Also, some of the larger firms appeared to have overcapitalized their businesses. Debt was burdening some producers excessively, even though in terms of variable costs they were operating competitively. Smaller producers, in contrast, may be undercapitalized, particularly with regard to postharvest storage facilities. This tendency by growers to either over- or underinvest in capital structures indicates the need to develop guidelines for building adequate but cost-effective facilities.

A final observation is that greater emphasis should be placed on the marketing end of the product. Regardless of firm size, prices 
received by growers were low, particularly given the prices paid in some markets.

\section{Literature Cited}

Lakaszewska, A.K. and L. Jablonska. 1991. Ornamental plant production in Poland. Chronica Hort. 31(3):35-37.

Mastalerz, J.W. 1969. Low temperature-dry storage, p. 35-37. In: J.W. Mastalerz and R.W. Langhan (eds.). Roses: A manual on the culture, management, diseases, economics, and breeding of greenhouse roses. Pennsylvania
Flower Growers, Roses, Inc., Pittsburgh.

Montenegro, D. 1989. Analysis of the Bolivian cut flower industry. MS Thesis, Arizona State Univ., Tempe.

Strain, J.R. and A.W. Hodges. 1989a. Business analysis of foliage plant nurseries in south Florida. Econ. Info. Rpt. 268, Food \& Resource Econ. Dept., Inst. of Food Agr. Sci., Univ. of Florida, Gainsville.

Strain, J.R. and A.W. Hodges. 1989b. Business analysis of flowering plant nurseries in Florida, 1986, 1987, 1988. Econ. Info. Rpt. 264, Food
\& Resource Econ. Dept., Inst. Food Agr. Sci., Univ. of Florida. Gainesville.

van Blokland, J. 1487. Introducing farm business analysis. Circ. 655, Florida Coop. Ext. Serv., Inst. Food Agr. Sci., Univ. of Florida, Gainesville.

University of Florida. 1992. Business analysis program. Inst. Food Agr. Sci. Food \& Resource Econ. Dept., Univ. of Florida, Gainesville.

U.S. Department of Agriculture. 1988. Floriculture crops: 1988 summary. $\mathrm{SpCr}$ 6-1 (89) Natl. Agr. Stat. Serv., Agr. Stat. Board, Washington, D.C. 